\title{
Microbial Load in Bonga Shad Fish (Ethmalosa fimbriata), Preservation Methods and Hygiene Practices among Fishmongers in Epe Community, Nigeria
}

\author{
Adetimehin Esther T, Hammed Taiwo B* and Adejumo Mumuni \\ Department of Environmental Health Sciences, University of Ibadan, Nigeria
}

Submission: February 05, 2019, Published: February 15, 2019

"Corresponding author: Hammed Taiwo B, Faculty of Public Health, Department of Environmental Health Sciences, College of Medicine, University of Ibadan, Ibadan, Nigeria

\begin{abstract}
This study was carried out to determine microbial load of fresh and smoked Bonga shad fish (Ethmalosa fimbriata) and hygiene practices among fishmongers in Epe town, Epe Local Government Area of Lagos State (Nigeria). Through a cross-sectional in design, a semi-structured questionnaire was administered on 44 consented fishmongers to collect data on their knowledge of fish contamination and spoilage, and their hygiene practices. Key informant interview guide also was used to collect data on fish preservation methods. In addition, 34 Bonga shad fish samples were collected for bacteriological analysis using standard methods. Quantitative data were analyzed using descriptive statistics and fisher's exact Chi-square at $\mathrm{p}=0.05$ while key informant interview responses were analyzed using thematic referent approach. Fishmongers' age was $37.1 \pm 10.8$ years; $90.9 \%$ were female while $45.5 \%$ had completed primary education. The major source of water supply reported by the fish mongers was stream (84.1\%). Significantly high proportion (77.8\%) of smoked fish sellers demonstrated good knowledge on fish contamination and spoilage. The major fish preservation methods identified in the study were smoking, salting, preservation with ice, and live fish preservation, using valium and paracetamol tablets. Predominantly identified microorganisms were fish spoilage micro-organisms. Education of fish mongers on the importance of maintaining good hygiene levels, and the use of treated water for fish processing are therefore recommended.
\end{abstract}

Keywords: Bonga shad fish; Fishmonger; Hygiene practices; Fish contamination; Fish preservation methods; Spoilage micro-organisms

\section{Introduction}

Fish is a major source of animal protein. However, it is susceptible to microbial contamination with organisms which are either naturally present in aquatic environments or from terrestrial sources. For instance, Ali and Hamza [1] confirmed that contamination of fish with microorganisms such as Vibrio sp. Salmonella sp, Staphylococcus typhi has been linked to poor personal hygiene, poor sanitation in handling, processing tools such as forklifts through leakage, opening in storage building and pests. Darlington and Stone [2] acknowledged that microbial contamination of fish could lead to spoilage in fish and also makes fishery products to be sources of various food-borne diseases. Han et al. [3] confirmed that bacterial infection from fish arises from ingestion of insufficiently heat-treated (smoked) or undercooked fish. Fish product could affect human health by inducing disease/ infection and causing abdominal pain, acute gastroenteritis, bloody/mucoid diarrhea, nausea, vomiting and fever. In a study by Kumolu and Ndimele [4], it was discovered that microbial contamination leads to the loss of 10-12 million metric tons of fish annually. This is a great economy loss to both fishermen and fish traders particularly when low quality fishes are sold at lower prices or discarded as unfit for human consumption. Therefore, Adebayo et al. [5] advocated prompt preservation or outright disposal of fish not meant for immediate consumption. This is to extend the shelf life of fish and other fishery products by applying the principles of chemistry, engineering and other branches of science in order to improve the quality of the products. Asiedu and Sanni [6] identified some methods of fish preservation which are freezing, salting, sun-drying, oven-drying, fermentation, prickling, irradiation, canning, and smoking.

A study by Nwiyi and Onyeabor [7] concluded that fish could be contaminated by microorganisms at the time of capture while more are added via unhygienic practices and contaminated equipment such as storage facilities. Rough handling could result in a faster spoilage rate. In addition, Adedeji and Adetunji [8] identified physical mishandling of fishnet in handling very large catches as a factor which could cause bruises and rupture of fish's blood vessels. They also identified careless actions such as fishermen stepping on fish and throwing boxes, containers and 
other items on top of the fish as other blood vessel-rupturing and -bruising practices. Microbial contamination of fish is an attack on fish by undesirable microorganisms (bacteria, yeast, mold, fungi, virus or their toxins and by-products) from external sources. Adegoke et al. [9] found Staphylococcus aureus, a mesophile, to be source of food poisoning outbreak of some food material. Relevant to this discovery, Adebayo et al. [5] confirmed that periwinkles harbor a lot of pathogenic microorganisms that pose serious health risks to the consumer. In studies carried out in Nigeria, Gram and Huss [10], and Wogu and Maduakor [11] identified presence of Salmonella, a fresh fish spoiler, in both fresh and smoked fish. Danba et al. [12] corroborated this claim by confirming that water used for fish processing was faecally contaminated.

Akinjogunla et al. [13] confirmed the presence microorganisms such as Escherichia coli, Staphylococcus aureus, Shigella sp., Aspergilus niger, and Vibro cholera in both fresh and smoked Bonga shad. This is indicative of faecal and environmental pollution due to poor handling and improper storage. These microorganisms are of public health importance in relation to food-borne diseases and fish spoilage. However, information on poor hygiene practices during handling and preservation of fishmonger in Nigeria is inadequate. This is particularly so important on fishes which are widely consumed locally such as Bonga shad fish, popularly called Efolo among the Yoruba. Abowei [14] described Bonga shad fish as catadromous freshwater fish which belongs to the family clupeidae and other clupiformes which George et al. [15] identified among the commercially exploited fishes for human consumption especially in Africa due to its cheap price. FAO [16] confirmed inadequacy or non-existence of food-borne disease surveillance in Nigeria which usually hinders government's ability to truly assess the impact of food-borne diseases arising from the consumption of contaminated fishery products. It is therefore imperative to determine microbial load of fresh and smoked Bonga shad and hygiene practices among fish mongers in Epe where the fish is not only major source of nutritious food but also on which almost the entire community members depend for income generation.

\section{Methods}

\section{Study area}

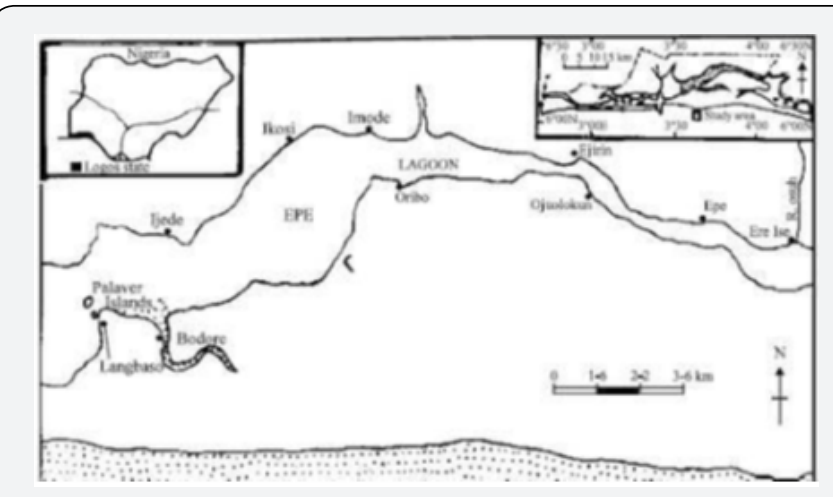

Figure 1: Map of Epe.
This study was carried out in Epe town (Figure 1) in Epe Local Government Area of Lagos State. Epe is located on the latitude 6' $31^{\circ} \mathrm{N}$ and longitude $40 \mathrm{E}$ and lies north east of Lagos metropolitan area. It is a riverine area which is located on a slightly elevated land that rises between about 30 and 60 meters above sea level. It is close to the shores of Lagos with the sheltered Lekki lagoon behind it. The climate is characterized by all years round precipitation and relatively high humidity and high temperature. The area experiences two seasons: the wet season between April and November, and the dry season between December and March. The temperature is generally high, the mean annual maximum is about $30{ }^{\circ} \mathrm{C}$ while the mean annual minimum temperature is about $23.8{ }^{\circ} \mathrm{C}$. The relative humidity is high throughout the year and ranges between $60 \%$ in January and over $80 \%$ in July. Epe is bounded by Ijebu-Ode to the north, Ikorodu and Ibeju- Lekki to the west, the lagoon and the Atlantic Ocean to the south, and by the creek to Benin River to the east. The inhabitants of Epe predominantly speak Ijebu, a dialect of Yoruba. The major festival annually celebrated in Epe is the Boat Regatta popularly called Okosi. Okosi is associated with rowing and sailing, and it is observed in order to appease the river goddess for greater fish harvest and protection against river accidents. The festival is usually observed within the month of March every year. Most of the inhabitants engage in fishing and farming activities for their livelihood. The major food of Epe indigenes is fish hence the appellation Epe Alaro which literally translates as Epe, the land of superabundant catfishs.

\section{Study design and instrument of data collection}

The study adopted a cross sectional design, comprising both survey and laboratory analysis. The study was conducted among 44 consented fishmongers in Epe town, Epe Logal Government Area, Lagos State. A set of validated semi-structured, researcheradministered questionnaire was developed to collect data on fishmonger's knowledge on fish contamination and spoilage, and hygiene practices. Also, key informant interviews (KIIs) were conducted to extract data on various fish preservation methods practiced by the fishmongers. In addition, fish samples were collected for bacteriological analysis using standard laboratory methods recommended by APHA [17].

\section{Data collection procedures}

Before commencement of the field work, a sensitization meeting was held with the fishmongers' association to discuss objectives of the study. In the meetings, it was ensured that the fishmongers demonstrated a high level of understanding of all aspects of the study. Completed and signed consent forms were obtained from the study's subjects (the fishmongers) who agreed to be included in the study. Knowledge of fishmongers on fish contamination was tested on a 14-point scale and scores $\geq 7$ were rated as good. The interviews were conducted by 4 trained Research Assistants (2 male and 2 female) who are university graduates acquainted with the questionnaire administration, key informant interview research and collection of environmental 
data samples. They were trained on how to use the instruments, and how to properly introduce themselves and the research objectives to the fishmongers during the interview.

For Bonga shad fish sampling and microbial determination, purposive sampling technique was used to collect a total of 34 samples of fish. Fresh fish samples were collected from Bonga fishermen upon arrival on shore, placed in ice-chest and transported to the laboratory. In addition, smoked fish and fresh fish samples were collected from Bonga fish sellers at a major market (chief market) in Epe. Polythene bags used to collect the fish samples were thoroughly cleaned and sterilized using $70 \%(\mathrm{v} / \mathrm{v})$ ethanol. The samples were tied inside the polythene bags, placed in ice-chest and transported to the laboratory for microbiological analysis. They were prepared according to recommended standard methods prescribed by the American Public Health Association [17]. The fresh fish were oven-dried at the temperature of $80{ }^{\circ} \mathrm{C}$ for $3 \mathrm{hrs}$. The fish flesh was removed using a sterile scalpel and pair of scissors; and pulverized with sterilized mortar and pestle for homogenization in order to obtain uniform distribution of cells. The fish tissue powder was sieved to obtain a fine powder on a sieve with $0.8 \mathrm{~mm}$ mesh size. The tissue powder was mixed with water sample by preparing one percent (1\%) suspension. Thereafter, insoluble materials were filtered using Whatman No. 1 filter paper and the clear solution was finally used for the microbial analyses.

Bacterial species were isolated according to the method of Akinjogunla et al. [13]. Serial dilutions 10-4 and 10-5 were used as the dilution factor. One milliliter was taken from each factor and plated out in the bacterial culture medium in duplicate. MacConkey and potato dextrose agar were the culture media used in the analyses. Characterization of the pure isolates was performed, and this involved colonial characteristics, cell micro morphology and biochemical test of gram reaction. Also, indole test, urease test, hydrogen sulfide production and coagulase tests were carried out. These tests were done to identify isolates to generic level in compliance with guidelines prescribed by Chessbrough [18].

\section{Data management and analysis}

The questionnaire data were edited daily to ensure completeness after which the cleaned data were entered into the computer using IBM SPSS version 22 software and analyzed. Results were presented in frequencies and percentages for categorical variables while mean, with standard deviation, was used to summarize the continuous variables. Fisher's exact test was used to determine the relationship between fish mongers' sociodemographic characteristics and knowledge category. Analysis of Variance (ANOVA) was used to compare the differences of bacterial and fungal loads between fish samples from fishermen, and fresh and smoked fish samples from the fish sellers. Furthermore, qualitative data (from KII) were transcribed, edited and saved using rich text format. Content analysis technique was adopted to analyze the data presented using thematic approach.

\section{Ethical considerations}

This study was approved by the University of Ibadan through the University College Hospital Joint Ethical Review Board before commencement of the field work. Also, permission was obtained from the fish monger association leaders. Individual interviews and collection of fish samples only started after the purpose of the study had been clearly explained to the participants and informed consent obtained. Participation was made voluntary and no form of coercion or undue influence was adopted. Participants were ensured confidentiality of all information obtained from them and, to assure this, respondents' names were not required to be written on the questionnaire copies in order to ensure anonymity.

\section{Results and Discussion}

\section{Socio-demographic characteristics of respondents}

Table 1: Socio-demographic characteristics of respondents.

\begin{tabular}{|c|c|c|}
\hline $\begin{array}{c}\text { Socio-Demographic } \\
\text { Characteristics }\end{array}$ & Frequency & $\%$ \\
\hline \multicolumn{3}{|c|}{ Age } \\
\hline$\leq 30$ & 13 & 29.5 \\
\hline $31-40$ & 18 & 40.9 \\
\hline $41-50$ & 8 & 18.2 \\
\hline$>51$ & 5 & 11.4 \\
\hline \multicolumn{3}{|c|}{ Sex } \\
\hline Male & 4 & 9.1 \\
\hline Female & 40 & 90.9 \\
\hline \multicolumn{3}{|l|}{ Religion } \\
\hline Christianity & 9 & 20.5 \\
\hline Islam & 35 & 79.5 \\
\hline \multicolumn{3}{|c|}{ Educational Level } \\
\hline No Formal Education & 6 & 13.7 \\
\hline Primary & 20 & 45.5 \\
\hline Secondary & 18 & 40.9 \\
\hline \multicolumn{3}{|c|}{ Years of Experience } \\
\hline $1-5$ & 6 & 13.6 \\
\hline $6-10$ & 19 & 43.2 \\
\hline $11-15$ & 8 & 18.2 \\
\hline$\geq 16$ & 11 & 25 \\
\hline \multicolumn{3}{|c|}{ Population Index } \\
\hline Fresh Fish Sellers & 35 & 79.5 \\
\hline Smoked Fish Sellers & 9 & 20.5 \\
\hline
\end{tabular}

Table 1 presents the socio-demographic characteristics of the 44 fishmongers that participated in this study. Their mean age was $37.1 \pm 10.8$ years (ranged between 19 and 61 years) and $40.9 \%$ of them were within the age range of 31-40 years. Most (90.9\%) of them were female, $79.5 \%$ practiced Islam, many (45.5\%) had completed primary education while $2.3 \%$ had post-secondary 
school certificates. Findings of this study corroborate with Zaman et al. [19] findings which shows that the fishmongers in their own study were middle aged and had attained the primary level of education. Also, 43.2\% of the respondents had spent between 6 and10 years in the occupation while $13.6 \%$ were fresh fish sellers (between 1 and 5 years).

Knowledge of respondents on fish contamination and spoilage

Table 2: Respondents' knowledge on fish contamination and spoilage.

\begin{tabular}{|c|c|c|}
\hline $\begin{array}{l}\text { *Knowledge State- } \\
\text { ments }\end{array}$ & Frequency & $\%$ \\
\hline \multicolumn{3}{|c|}{ Causes of Fish Spoilage } \\
\hline Unhygienic handling & 19 & 43.2 \\
\hline $\begin{array}{l}\text { Microbial contami- } \\
\text { nation }\end{array}$ & 5 & 11.4 \\
\hline Lack of preservation & 32 & 72.7 \\
\hline \multicolumn{3}{|c|}{ Indicators of Fish Spoilage } \\
\hline Foul smell & 39 & 88.6 \\
\hline Physical deterioration & 40 & 90.9 \\
\hline \multicolumn{3}{|c|}{ Consumption of Contaminated Fish Leading to Food Poisoning } \\
\hline Yes & 22 & 50 \\
\hline No & 22 & 50 \\
\hline \multicolumn{3}{|c|}{ Prevention of Fish Spoilage } \\
\hline Smoking & 32 & 72.7 \\
\hline Freezing & 12 & 27.3 \\
\hline
\end{tabular}

Table 2 shows the fishmongers' knowledge on fish contamination and spoilage. Majority (72.7\%) reported that lack of preservation caused fish spoilage while $43.2 \%$ and $11.4 \%$ stated that unhygienic handling and microbial contamination respectively caused fish spoilage. This is similar to the findings of Nwiyi and Onyeabor's [7] study in which it was reported that rough handling results in a faster spoilage rate. The major indicators of fish spoilage reported were physical deterioration (90.9\%) and foul smell (88.6\%). However, in a related study, Emikpe et al. [20] reported that contamination of fish from enteric bacteria of human and animal origins may be responsible for various food spoilages. Indeed, Akinjogunla et al. [13] have attributed the presence of bacteria in both fresh and smoked Bonga fish to fecal and environmental pollution due to poor handling and improper storage. A half (50.0\%) of the fishmongers reported that consuming contaminated fish caused fish poisoning while $72.7 \%$ said that smoking was the best prevention of fish spoilage.

Fishmongers' mean knowledge score was $7.3 \pm 1.5$ and $40.9 \%$ had good knowledge on fish contamination and spoilage (Figure 1). Category of fishmongers' knowledge was compared with their demographic characteristics (Table 3). Respondents' sex, educational level and years of experience did not show any significant association with their knowledge category. These findings suggest that sex, educational level and years of experience may not be associated with fishmongers' knowledge. However, the proportion of fishmongers who had good knowledge was significantly higher at the age of $>50$ years $(80.0 \%)$ compared to any other age category. Significantly, high proportion $(77.8 \%)$ of smoked fish sellers had good knowledge on fish contamination and spoilage compared to their counterparts that sold fresh fish (31.4\%) (Figure 2).

Table 3: Comparison of socio-demographic characteristics with category of knowledge on fish contamination and spoilage.

\begin{tabular}{|c|c|c|c|c|}
\hline \multirow{2}{*}{$\begin{array}{l}\text { Character- } \\
\text { istics }\end{array}$} & \multicolumn{2}{|c|}{ Knowledge Category } & \multirow{2}{*}{$\begin{array}{c}\chi 2 \text { (Fish- } \\
\text { er's Exact) } \\
\text { Test }\end{array}$} & \multirow{2}{*}{ p-Value } \\
\hline & Poor (\%) & Good (\%) & & \\
\hline \multicolumn{5}{|c|}{ Age } \\
\hline$\leq 30$ & $11(84.6)$ & $2(15.4)$ & 6.737 & 0.028 \\
\hline $31-40$ & 7 (38.9) & $11(61.1)$ & & \\
\hline $41-50$ & $3(37.5)$ & $5(62.5)$ & & \\
\hline$>51$ & $1(20.0)$ & $4(80.0)$ & & \\
\hline \multicolumn{5}{|c|}{ Sex } \\
\hline Male & $2(50.0)$ & $2(50.0)$ & 0.148 & 0.7 \\
\hline Female & $24(60.0)$ & $16(40.0)$ & & \\
\hline \multicolumn{5}{|c|}{ Educational Level } \\
\hline $\begin{array}{l}\text { No Formal } \\
\text { Education }\end{array}$ & $4(66.7)$ & $2(33.3)$ & 2.147 & 0.555 \\
\hline Primary & $10(50.0)$ & $10(50.0)$ & & \\
\hline Secondary & $11(61.1)$ & $7(38.9)$ & & \\
\hline \multicolumn{5}{|c|}{ Years of Experience } \\
\hline $1-5$ & $3(50.0)$ & $3(50.0)$ & 6.025 & 0.107 \\
\hline $6-10$ & 15 (78.9) & $4(21.1)$ & & \\
\hline $11-15$ & $4(50.0)$ & $4(50.0)$ & & \\
\hline$\geq 16$ & $4(36.4)$ & $7(63.6)$ & & \\
\hline \multicolumn{5}{|c|}{ Population Index } \\
\hline $\begin{array}{c}\text { Fresh Fish } \\
\text { Sellers }\end{array}$ & $24(68.6)$ & $11(31.4)$ & 6.425 & 0.021 \\
\hline $\begin{array}{c}\text { Smoked } \\
\text { Fish Sellers }\end{array}$ & $2(22.2)$ & $7(77.8)$ & & \\
\hline
\end{tabular}

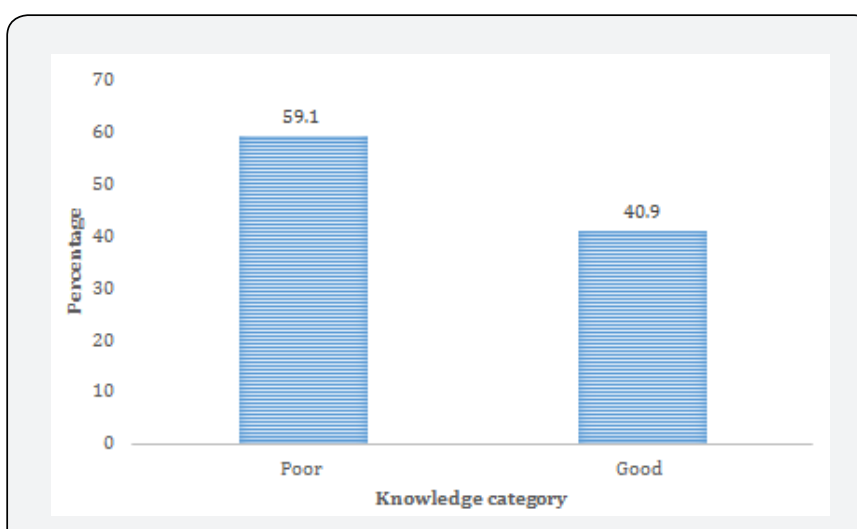

(Knowledge score: $7.3 \pm 1.5$ (minimum=6, maximum=11)).

Figure 2: Respondents' knowledge on fish contamination and spoilage. 


\section{Sources of water supply and hygiene practices among fish mongers}

Table 4: Sources of water supply and hygiene practices among fish mongers.

\begin{tabular}{|c|c|c|}
\hline $\begin{array}{c}\text { Sources of Water } \\
\text { Supply and Hygiene } \\
\text { Practices }\end{array}$ & Frequency & $\%$ \\
\hline \multicolumn{3}{|c|}{ *Sources of Water Supply } \\
\hline Stream & 37 & 84.1 \\
\hline Well & 21 & 47.7 \\
\hline Borehole & 10 & 20.5 \\
\hline \multicolumn{3}{|c|}{ *Respondent's Tme of Hand-Washing } \\
\hline After using the toilet & 17 & 38.6 \\
\hline Before handling fish & 15 & 34.1 \\
\hline After handling fish & 15 & 34.1 \\
\hline At the end of the day & 30 & 68.2 \\
\hline $\begin{array}{l}\text { After coughing/ } \\
\text { sneezing }\end{array}$ & 0 & 0 \\
\hline \multicolumn{3}{|c|}{ Respondent's Method of Hand-Washing } \\
\hline Soap and water & 31 & 70.5 \\
\hline Water & 13 & 29.5 \\
\hline \multicolumn{3}{|l|}{ *Use of PPE } \\
\hline Apron & 9 & 20.5 \\
\hline Hand gloves & 2 & 4.5 \\
\hline Nose mask & 0 & 0 \\
\hline Head covering & 0 & 0 \\
\hline \multicolumn{3}{|c|}{ Immediate Removal of Gills After Slaughtering } \\
\hline Yes & 12 & 27.3 \\
\hline No & 20 & 45.5 \\
\hline Sometimes & 12 & 27.3 \\
\hline
\end{tabular}

* = Multiple responses

The major source of water supply reported by the fishmongers was stream (84.1\%), well (47.7\%) and borehole $(20.5 \%)$ as presented in Table 4. Akinjogunla et al. [13] identified stream as a source of contamination to fish products. Stream is a popular water source for processing fish as revealed by Alam et al. [21] who confirmed that about half of fish mongers in Bangladesh used stream water to process their fish. Majority (68.2\%) of the respondents in this study reported that they washed their hands at the end of the day, 38.6\% said they carried out hand-washing after using the toilet, $34.1 \%$ stated that they washed their hands before handling fish while $34.1 \%$ revealed that they washed their hands after handling fish. Majority (70.5\%) of the fish mongers reported that they used soap and water for hand-washing while $29.5 \%$ said they used water only. Few (20.5\%) of the fish mongers reported that they used apron while $4.5 \%$ stated that they used hand gloves during fish handling.

\section{Methods of preserving bonga fish in the area}

The major fish preservation methods reported during the key informant interviews were smoking, salting, preservation with ice and live fish preservation. One of the key informants narrated that there were two methods of preservation with ice, and that the two methods could keep the fish fresh for up to four days. The informant further described the process, "the first thing we do is to remove the gills, intestines and scales from the fish. Then we place a sack in a basket that is under-laid with either leaves or cartons to prevent seepage from melted ice. We place ice cubes on the leaves in sufficient quantity and fish on top of the ice. Thereafter, we place salt, seasoning, sliced onions and tomatoes in sufficient quantity on the fish. We put another layer of fish, following the previous step till the sac is filled up. We make sure the ice cubes are replenished at intervals (mostly on a daily basis)" (KII: fresh fish seller, chief market).

Another key informant reported that some species of fish could be preserved by live fish preservation technique. A fresh fish seller and key informant mentioned knife fish (Cymmorchus niloticus) as the main fish species that could be preserved with this method. She said that fish mongers usually made use of valium and paracetamol tablets on fishes. Valium tablets were to prevent the fishes from feeding on one another while paracetamol made the fishes stronger. The key informant stated that this method could preserve the fish alive for one to two weeks. Smoking was said to be the most preferred and widely used method of fish preservation. An informant explained the process, "to preserve fish by smoking, we need to remove the gills, intestines and scales from fish after slaughter. Then we wash, drain and season the fish. Sometimes we use salt, maggi or both as season. We then place the fish on wire gauze and heat for at least an hour. Sometimes we heat for about 7-9 hours consecutively for 2-days in order to keep the fish up to 2 weeks" (KII: smoked fish seller).

Evisceration and removal of gills from fish immediately after slaughter is a practice that reduces the rate of deterioration of fish. However, fish mongers hardly take this necessary preventive measure. This information corroborates that of Sarker et al. [22] where majority of the fish mongers conceded they were not used to removing gills immediately after fish slaughter. In this study, the major reported fish preservation techniques were salting, smoking, preservation with ice, and live fish preservation, corroborating the previous study of Asiedu and Sanni [6]. It was also found that some of these methods require fish mongers removing the gills, intestines and scales from the fish to be preserved after slaughter. Other methods involved the addition of spices such as salt, seasoning, sliced onions and tomatoes to the preserved fish. However, there are some concerns about the use of some drugs like valium and paracetamol in live fish preservation methods. Valium, a drug belonging to the benzodiazepine family, might have some side effects being associated with its use. Obliviously, fish consumers might ingest part of this drug which could lead to some 
negative health effect. Nevertheless, most of the fish mongers stated that smoking was the best prevention of fish spoilage. This is in agreement with Maga [23] who considered smoking process as a mild preservative treatment, which kills bacteria and prevents microbial proliferation due to combined effects of heating, drying, $\mathrm{pH}$ and antimicrobial smoke components.

\section{Microbial loads in fresh and smoked fish}

Table 5: Sources of water supply and hygiene practices among fish mongers.

\begin{tabular}{|c|c|c|c|c|c|}
\hline \multirow{2}{*}{$\begin{array}{c}\text { Parame- } \\
\text { ters }\end{array}$} & $\begin{array}{c}\text { Fresh Fish } \\
\text { (Fisher- } \\
\text { men) }\end{array}$ & $\begin{array}{c}\text { Fresh Fish } \\
\text { (Seller) }\end{array}$ & $\begin{array}{c}\text { Smoked } \\
\text { Fish }\end{array}$ & $\begin{array}{c}\text { F-sta- } \\
\text { tistics }\end{array}$ & $\begin{array}{c}\text { p-Val- } \\
\text { ue }\end{array}$ \\
\hline $\begin{array}{c}\text { Total } \\
\text { Viable } \\
\text { Bacterial } \\
\text { Count } \\
\text { (cfu/g) }\end{array}$ & $\begin{array}{c}(1.7 \pm 0.05) \\
\times 105\end{array}$ & $\begin{array}{c}(1.8 \pm 0.06) \\
\times 105\end{array}$ & $\begin{array}{c}(3.0 \pm 0.09) \\
\times 105\end{array}$ & 10.129 & 0.013 \\
\hline $\begin{array}{c}\text { Fungal } \\
\text { Count } \\
\text { (cfu/g) }\end{array}$ & $\begin{array}{c}(2.3 \pm 1.0) \times \\
105\end{array}$ & $\begin{array}{c}(2.5 \pm 0.07) \\
\times 105\end{array}$ & $\begin{array}{c}(2.6 \pm 0.08) \\
\times 105\end{array}$ & 9.413 & 0.025 \\
\hline
\end{tabular}

The bacterial and fungal counts of fish samples are presented in Table 5. The total viable bacterial count (cfu/g) was significantly higher in smoked fish samples [(3.0 \pm 0.09$) \times 105]$ compared to fresh fish samples from the sellers [(1.8 \pm 0.06$) \times 105]$, and fresh fish from fishermen $[(1.7 \pm 0.05) \times 105]$. Fungal count $(\mathrm{cfu} / \mathrm{g})$ of the smoked fish, fresh fish from the sellers and fresh fish from fishermen were $(2.6 \pm 0.08) \times 105 ;(2.5 \pm 0.07) \times 105$; and $(2.3 \pm 1.0) \times 105$ respectively. The observed difference between the fungal count within the fresh and smoked fish samples was statistically significant at $5 \%$ level of significance. Also, there was a significantly higher bacterial and fungal load in the smoked fish compared to the fresh fish samples. This could be attributed to poor hygiene practice during handling and smoking processes. The reason could as well be an indication of partial dehydration during smoking and unhygienic display at market stalls, as earlier observed by Dike-Ndudim et al. [24].

\section{Bacterial and fungal isolates from fresh and smoked bonga fish}

The organisms identified in fresh and smoked Bonga fish are presented in Tables 6. Smoked fish samples had more isolates (11 bacterial species and 6 fungal species) than did the fresh fish samples ( 5 bacterial species and 4 fungal species). The types of bacterial and fungal isolates in both fresh and smoked fish samples are similar to those previously observed in other studies by Akinjogunla et al. [13] and Wogu and Maduakor [11]. These bacterial and fungal species were found to be fish spoilage-causing microorganisms which could also cause food poisoning. Gram and Huss [10] reported that bacillus bacteria species is a major cause of microbial spoilage of fresh fish after capture. Morales et al. [25] confirmed bacillus sp. to be a source of infectious diseases such as abscesses, bacteremia, wound and foodborne infections, ear infections, endocarditis meningitis, ophthalmitis, osteomyelitis, peritonitis, and respiratory and urinary infections.
Table 6: Microbial isolates in the selected fresh and smoked Bonga fish.

\begin{tabular}{|c|c|c|c|}
\hline \multicolumn{2}{|c|}{ Microbial isolates } & Fresh Fish & Smoked Fish \\
\hline \multirow{12}{*}{$\begin{array}{c}\text { Bac- } \\
\text { terial } \\
\text { Isolates }\end{array}$} & $\begin{array}{l}\text { Bacillus } \\
\text { pumilus }\end{array}$ & - & + \\
\hline & $\begin{array}{c}\text { Entero- } \\
\text { bacter } \\
\text { aerogenes }\end{array}$ & - & + \\
\hline & $\begin{array}{c}\text { Pseudo- } \\
\text { monas } \\
\text { fluorescens }\end{array}$ & + & + \\
\hline & $\begin{array}{l}\text { Bacillus } \\
\text { licheni- } \\
\text { formis }\end{array}$ & - & + \\
\hline & $\begin{array}{l}\text { Staphy- } \\
\text { lococcus } \\
\text { aureus }\end{array}$ & - & + \\
\hline & $\begin{array}{c}\text { Bacillus } \\
\text { megateri- } \\
\text { um }\end{array}$ & + & + \\
\hline & $\begin{array}{l}\text { Bacillus } \\
\text { subtilis }\end{array}$ & + & + \\
\hline & $\begin{array}{c}\text { Flavobac- } \\
\text { terium } \\
\text { aquatile }\end{array}$ & + & + \\
\hline & $\begin{array}{l}\text { Pseudomo- } \\
\text { nas aerugi- } \\
\quad \text { nosa }\end{array}$ & - & + \\
\hline & $\begin{array}{l}\text { Proteus } \\
\text { vulgaris }\end{array}$ & - & + \\
\hline & $\begin{array}{l}\text { Proteus } \\
\text { mirabilis }\end{array}$ & + & + \\
\hline & Yersinia $s p$ & + & - \\
\hline \multirow{6}{*}{$\begin{array}{c}\text { Fungi } \\
\text { Isolates }\end{array}$} & $\begin{array}{l}\text { Aspergillus } \\
\text { flavus }\end{array}$ & + & + \\
\hline & $\begin{array}{l}\text { Penicillum } \\
\text { atrovene- } \\
\text { tum }\end{array}$ & + & + \\
\hline & $\begin{array}{l}\text { Saccha- } \\
\text { romyces } \\
\text { cerevisae }\end{array}$ & + & + \\
\hline & $\begin{array}{c}\text { Mucor } \\
\text { hiemalis }\end{array}$ & + & + \\
\hline & $\begin{array}{c}\text { Rhiozopus } \\
\text { sp }\end{array}$ & - & + \\
\hline & $\begin{array}{c}\text { Alternaria } \\
\text { sp }\end{array}$ & - & + \\
\hline
\end{tabular}

Note: - = Isolates Absent; + = Isolates present

The isolation of B. licheniformis, B. subtilis and $S$. aureus in smoked fish samples is an indication of poor handling or cross contamination of smoked fish products. B. licheniformis is mostly associated with soil. Its occurrence in smoked fish samples could have arisen from dust from the surrounding environments getting into fish products due to the open display of fish products without any top covering. It is important to note that majority of the fungal isolates are of medical importance. For instance, Aspergillus flavus has a high potential in producing aflatoxin which Ayolabi and 
Fagade [26] reported as causing acute hepatisis (aflatoxicosis). They further identified Penicillum sp., Alternaria sp. and Aspergillus $s p$. as sources of food spoilage which are traceable to water and soil with which the fish is in contact. Okareh and Erhahon [27] also confirmed that Staphylococcus sp. are pathogenic strains which could cause food poisoning due to the heat stable staphylococcus enterotoxin which is resistant to gastrointestinal enzymes. Similarly, Morales et al. [25] claimed that staphylococcal food contamination is usually traced to workers who are carriers and/or in contact with inadequately cleaned equipment while Pseudomonas aeruginosa and Proteus mirabilis produce severe pneumonia [28].

\section{Conclusion}

This study evidently reveals that the hygiene practices among the fish mongers in Epe were very poor. Majority of the fishmongers did not use personal protective equipment during fish handling and processing. The reported main source of water was stream which might be grossly contaminated with various species of microorganisms. Smoking was the prevalent method of fish preservation; others included icing, salting and live fish preservation. However, the live preservation methods involve the use of valium, a drug belonging to the benzodiazepine family which might have some side effects associated with its use. The microbial load in smoked Bonga fish was more than that of fresh fish samples. The predominant microorganisms are fish spoilage micro-organisms. In view of these discoveries, it is suggested that fish mongers should be adequately educated on maintaining proper hygiene and the importance of personal protective equipment usage during fish processing. The use of treated water should be encouraged during fish processing while smoked fish should be hygienically handled to reduce fish contamination. Further studies should also be carried out on the effect of using valium in live fish preservation on health.

\section{Acknowledgement}

The authors wish to acknowledge the fishmongers associations and the individuals that contributed towards the success of this study.

\section{Conflicts of interest}

The authors declare no conflicts of interest as regards the publication of this paper.t.

\section{References}

1. Ali MA, Hamza MI (2004) Prevalence of seafood borne pathogens in shellfish at retail level. First Annual Conference Faculty Veterinary Medicine, Moshtohor, Egypt.

2. Darlington LG, Stone TW (2001) Antioxidants and fatty acids in the amelioration of rheumatoid arthritis and related disorders. Br J Nutr 85(3): 251-269.

3. Han BZ, Beumer FM, Nout M (2001) Microbiological safety and quality of commercial Tofu- a Chinese fermented soybean food. Food Control 12: 541-547.
4. Kumolu-Johnson CA, Ndimele PE (2011) Length-weight relationships of nine fish species from Ologe Lagoon, Lagos, Nigeria. African Journal of Biotechnology, 10(2): 241-243.

5. Adebayo BC, Onllude AA, Ogunjobi AA (2006) Bacteriological and proximate analysis of periwinkle from two different creeks in Nigeria. World Applied Science Journal 1(2): 87-91.

6. Asiedu M, Sanni AI (2002) Chemical composition and microbiological changes during spontaneous and starter culture fermentation of Enam Ne-Setaakye, a West African fermented fish-carbohydrate product. European Food Research Technology 215(1): 8-12.

7. Nwiyi P, Onyeabor A (2012) Occurrence of Salmonella spp. from fresh fish (Tilapia niloticalinn) using improved isolation methods. Online Journal of Animal Feed Research 2(6): 475-478.

8. Adedeji OB, Adetunji VO (2004) Pests in farm animals and stored animal products. In: Agriculture, Renewable Natural Resources, Animal Husbandry and Health, UI Press, University of Ibadan, Nigeria, pp. 141151.

9. Adegoke AA, Adebayo BC, Akinjogunla OJ (2009) Microbial and physicochemical quality of powdered soymilk samples in Akwa Ibom, South Southern Nigeria. African Journal of Biotechnology 8(13): 3066-3071.

10. Gram L, Huss HH (2001) Microbiological spoilage of fish and fish products. Int J Food Microbiol 33(1): 121-137.

11. Wogu MD, Maduakor CC (2010) Evaluation of Microbial Spoilage of Some Aquacultured Fresh Fish in Benin City Nigeria. Ethiopian Journal of Environmental Studies and Management 3(3): 18-22.

12. Danba EP, Bichi AH, Ishaku S, Ahmad MK, Buba U, et al. (2014) Occurrence of Pathogenic Bacteria Associated with Clarias Gariepinus in Selected Fish Farms of Kumbotso Local Governement Area of Kano State, Nigeria. Bayero Journal of Pure and Applied Sciences 7(2): 145149.

13. Akinjogunla OJ, Inyang CU, Akinjogunla VF (2011) Bacterial species associated with anatomical parts of fresh and smoked bonga fish (Ethmalosa fimbriata): Prevalence and susceptibility to cephalosporins. Research Journal of Microbiology 6(1): 87-97.

14. Abowei JFN (2009) The morphology, abundance, condition factor and length weight relationship of Ethmalosa fimbriata (bowdich 1825) from Nkoro River Niger Delta, Nigeria. Advance Journal of Food Science Technology 1(1): 51-56.

15. George UU, Idung JU, Andem AB, Okorafor KA, Mowang D (2013) Diet composition and condition factor of Ethmalosa fimbriata in the crossriver estuary. Greener Journal of Biological Sciences 3(6): 244-252.

16. FAO (2007) Survey Methods of Appraising Evaluation of traditional solar dry system in Nigeria Fisheries Resource. Fish Technical Paper, pp. 171.

17. American Public Health Association (APHA) (2005) Standard Methods for the Examination of Water and Wastewater (21 $1^{\text {st }}$ edn), Washington DC: American Public Health Association, pp. 1220.

18. Cheesbrough M (2002) District Laboratory Practice in Tropical Countries. (Part II) (2 $2^{\text {nd }}$ edn), Tropical Health Technology Publishers, Great Britain. pp. 40-56.

19. Zaman T, Jeweland MAS, Bhuiyan AS (2006) Present status of pond fishery resources and livelihood of the fish farmers of mohanpur upazila in Rajshahi District. University Journal of Zoology, Rajshahi University 25: 31-35.

20. Emikpe BO, Adebisi T, Adedeji OB (2011) Bacteria load on skin and Stomach of Clarias gariepinus and Oreochromis niloticus from Ibadan, Southwest Nigeria: Public health implications. Journal of Microbiology and Biotechnology Research 1(1): 59-62. 
21. Alam MM, Haque MM, Shikha FH (2014) Studies on public health and hygiene condition of retailers at fish markets in south-central Bangladesh. J. Bangladesh Agril Univ 12(2): 411-408.

22. Sarker T, Ahmed O, Oluwo J (2017) Hygiene practices among fish handlers. Journal of Fish Research 22: 643-652.

23. Maga J (1988) Smoke in Food Processing. ( $1^{\text {st }}$ edn), Boca Raton Florida, United States: CRC Press, pp. 168

24. Dike-Ndudim JN, Egbuobi RC, Onyeneke EN, Uduji HI, Nwagbaraocha MA, et al. (2014) Microbial Status of Smoked Fish, Scombia Scombia Sold in Owerri, Imo State, Nigeria. African Journal of Clinical and Experimental Microbiology 15(1): 35-39.

25. Morales J, Moreno J, Merino S, Tomas G, Martinez J, et al. (2004) Association between immune parameters, parasitism and stress in breeding pied fly catcher blue tits (parus caeauleus) a medication field experiment. Annales Zoological fennici 42: 45-56.

26. Ayolabi IC, Fagade EO (2010) Mycological evaluation of smoked fish (Ethmalosa fimbriata) from retail outlets in Ago-Iwoye, Ogun state, Nigeria. Journal of life and physical science 3(2): 64-68.

27. Okareh OT, Erhahon 00 (2015) Microbiological Assessment of Food and Hand-Swabs Samples of School Food Vendors in Benin City, Nigeria. Food and Public Health 5(1): 23-28.

28. Adeyeye SA, Oyewole OB, Obadina AO, Omemu AM, Oyedele HA, et al. (2015) A survey on traditional fish smoking in Lagos State, Nigeria. African Journal of Food Science 9(2): 59-64.

\section{Your next submission with Juniper Publishers will reach you the below assets}

- Quality Editorial service

- Swift Peer Review

- Reprints availability

- E-prints Service

- Manuscript Podcast for convenient understanding

- Global attainment for your research

- Manuscript accessibility in different formats

( Pdf, E-pub, Full Text, Audio)

- Unceasing customer service

Track the below URL for one-step submission https://juniperpublishers.com/online-submission.php 